\title{
INTERDEPENDENCE OF COMPANY'S INDUSTRIAL COMPETITIVE POSITION AND ITS STRATEGIC ORIENTATION: A DYNAMIC THEORETICAL MODEL
}

\author{
Vladimir Gnjidic ${ }^{*}$
}

Received: 21. 3. 2015

Preliminary communication

Accepted: 7. 12. 2018

UDC 005.21:338.2

DOI https://doi.org/10.30924/mjcmi/2018.23.2.103

\begin{abstract}
This paper offers a conceptual model for revealing dynamic interdependence between company's competitive position using Porter's analytical framework "five competitive forces" and its strategic orientation as defined by Miles and Snow's strategic typology of organizational behaviour. As both models have been criticized for its static nature not fitting contemporary market dynamis, the proposed reciprocity of interrelationship between industrial structure and company's conduct in different time periods, provides a modern alternative for making strategic choices. The author suggests a theoretical correlation between company's previous, current
\end{abstract}

\section{INTRODUCTION}

Fundamental questions of strategic management, since its origins, have been related to: (1) the reasons for better performance of some companies, compared to their competitors, as well as (2) the quality of research tools and techniques used to answer the first question.

The difference in performances of companies is determined, among other factors, by the extent to which they understand and are able to adapt to their environment, and anticipated competitive positions with its previous, current and planned type of strategic behaviour. Accordingly, dynamically consistent successful strategic types (prospector, analyst, and defender) should be connected to the above average dynamical competitive positions. The proof of existence of such a correlation would indicate company's consistent ability to successfully adapt to (consistently changing) industrial environment.

Keywords: competitive position, strategic orientation, dynamic interdependence

in accordance with the traditional Bain's (1951) S-C-P paradigm (Structure $\rightarrow$ Conduc $\mathrm{t} \rightarrow$ Performance). Defining the position of a company in its micro-environment enables the management to identify key strengths, weaknesses, opportunities, and threats, to consider the overall potential, i.e. to develop the strategic direction of the company, with the aim of achieving above-average profits. The lack of adequate knowledge or failure to perform an adequate analysis of the business environment may lead to business myopia within the inductive approach to the company's strategic orientation.

\footnotetext{
*Vladimir Gnjidić, PhD, Metro Cash \& Carry Croatia plc, Jankomir 31, 10090 Zagreb, Croatia; e-mail: vgnjidic@ net.hr; phone: 00385913444327
} 
It additionally becomes important in contemporary fast-changing environmental context, in which consistent behavioural pattern may not reflect optimal organizational adjustment to the influence brought by determinants of industrial structure.

Dulčić et al. (2012) suggested that "firm's past, present and future strategic behavior in combination with past, present and anticipated character of industry's structure determinants create the basis for different competitive position of the firm (i.e. its position among its direct competitors, being result of the influence of industry structure's determinants on firm's performance)". In relation with the aforementioned "strategic behaviour", Hambrick (1983) recommended the future use of Miles and Snow's typology for "researching ways of relating the strategy to the company environment". Desarbo et al. (2004) believe that the optimal approach to relating organizational strengths to the strategic organizational types should include environmental attributes.

In order to capture the way how, in a longer period of time, industrial environment shapes organizational behaviour, the research goal of this paper is to offer a theoretical model framing the correlation between company's competitive position in an industry with its strategic behaviour pattern.

Research questions for consideration are: 1) How to define a company's competitive position in the industrial environment? 2) How to capture company's competitive position over a longer period of time? 3) How to frame dynamic interdependence between company's competitive position and its strategic behaviour?

\section{CONCEPTUALISATION OF THE COMPETITIVE POSITION OF A COMPANY IN THE INDUSTRIAL ENVIRONMENT}

Porter's Five Forces analytical framework is the most often defined and used strategic tool useful for industrial analysis. Although Porter (1998) himself claims "the tool is applicable in every industry and to every company", examples of its implementation at the company level are rare (e.g. Dess et al., 1990), as well as the attempts of its quantification (e.g. Pecotich et al., 1999). Apart from the originally inexistent form of quantification, one of the often criticized parts of Porter's concept is the industrial aspect, given the perception of the growing importance of key competencies of organizations at the end of the last century ${ }^{1}$.

Dess et al. (1990) claim that the characteristics of an overall industrial structure cannot be assumed as representative, i.e. they cannot be expected to have similar effects on all companies within a particular industry. Accordingly, Rumelt (1991) believes that the heterogeneity of companies within the same industry explains the economic performance of companies more clearly, than belonging to a particular industry. Chen (1996) has made a synthesis of issues related to competitive analysis and rivalry among companies. Unlike Porter's Five Forces concept, which operates at the industrial level analysis, Chen's model focuses on company level and provides an insight into the study of competitive dynamics ${ }^{2}$.

The potential of overcoming the criticism of industrial level analysis of the

\footnotetext{
${ }^{1}$ More recent studies indicate equal importance of both external and internal factors in determining the level of performance (Chen, 1996; Hooley et al., 1998; Morgan et al., 2003; Desarbo et al., 2004).

${ }^{2}$ Chen proves the parallel appropriateness of Porter's deductive approach to finding the source of competitive advantage, as well as of the inductive one which results from the Resource-Based view.
} 
model is summarized in the point of view of each individual, as well as the combined effect of all competitive forces. The most common instruments to conduct the five forces-based analysis are surveys, incorporating nominal variables, or interviews, resulting in descriptive characteristics of collective (industrial) effect of competitive forces. It is a rare exception that an individual company (i.e. an existing industrial participant) is made the center of observation and that the results are quantified in the relative context (see Figure 1).

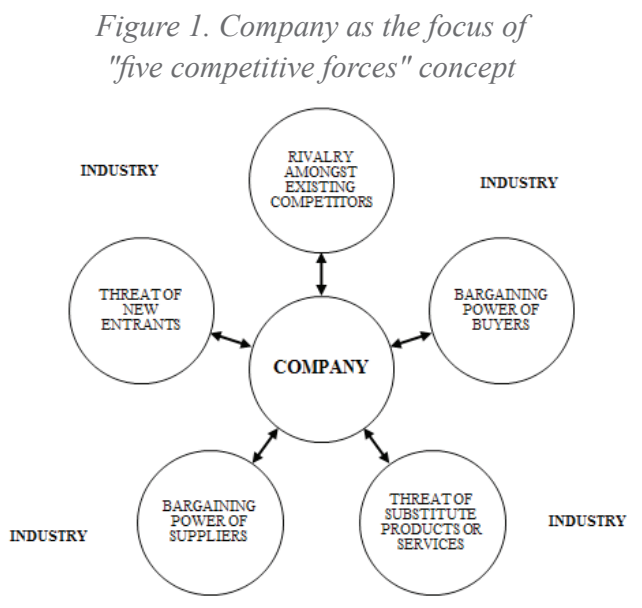

Source: Author's adjustment of the original Porter's framework (1979)

The importance of considering the "position-related" strategic performance of a company in relation with the environment is also highlighted by Mintzberg (1987), although he was one of the most prominent critics of Porter's school of industrial positioning. He defines the term strategy (among other concepts) as a "position", i.e. "a mediating force between the organization and the environment, i.e. between the internal and the external context". Porter (1981) derives his analysis of the industrial structure from the paradigm of industrial organization, in which strategic choices and industrial structure explain the level of performance of companies in an industry ${ }^{3}$. According to Porter (1991), one of the objectives of company's behaviour is to influence industrial forces in such a way so as to change them in company's favour. This is matched by his definition of strategy as "an act of mutual adaptation of a company and its environment", and not only the adaptation of a company to its environment. Thus, the industrial structure for Porter (1991) is "partly exogenous and partly subject to influence of company's behavior”.

The model for analysis of industrial structure proposed by M.E. Porter (1979) primarily refers to the selection of company's strategic behaviour through: (1) strategic positioning - defining the optimal position of a company in the industrial environment in relation to the impact of competitive forces; (2) strategic action - acting towards changing the impact of competitive forces, with either the aim of neutralizing them, or shifting the adverse influences into favourable ones; (3) anticipation of industrial development - in order to adapt the types of strategic actions to the anticipated changes in the industrial structure. In order to build competitive advantage and achieve above-average rates of return, the company should apply those forms of strategic orientation that will ensure it a more favourable competitive position, compared to other companies in the industry. Therefore, the company should strive for taking an optimal competitive position in the industrial environment by observing the existing relative competitive constellation and its competitive position in it.

It is necessary to make a clear distinction between the concepts of strategic

\footnotetext{
${ }^{3}$ Although, soon after, a number of researchers advocated combining industrial organisation and the perspective of strategic management (Jemison, 1981; Bourgeois, 1984, Barney \& Ouchi, 1986)
} 
positioning and competitive position. The concept of strategic positioning can be conceptualized as a dynamic action (process) which does not necessarily need to be completed, and which aims at determining the target (ideal) competitive position of the company. Meanwhile, organized activities are undertaken that implement the selected strategic actions/orientations/patterns ${ }^{4}$ with the intention of taking it. The decision on the target competitive position of a company should be derived from a detailed analysis of the ability to oppose the analysed competitive forces. Fahy and Smithee (1999) define strategic market positioning as ways in which specific company resources and funds are used to establish a positional advantage at product markets. Eng (2004) claims that it is based on three generic strategies (cost leadership, differentiation and focus), and it is a function of the number of markets served and the degree of vertical integration. The described conceptualization indicates the interdependence of company's strategic orientation and its (target) positions within the industry.

Alfirević et al., (2014) presented a research model in which they showed the interrelatedness of a company's strategic orientation and the perceived industrial activity, treated as the (industry-related) relative performance of the company. In their paper, these authors presented preliminary results of an empirical research on a sample of medium and large companies in the Croatian food and beverage industry. The existence of a causal link between reverse elements of the classical S-C-P paradigm $(\mathrm{S} \rightarrow \mathrm{P} \rightarrow \mathrm{C})$ was suggested in this study. The authors also introduced a "relative competitive position", which "honors the differences in direction and intensity of individual competitive forces, as well as their combined influence to a single entity" (p. 86). However, the authors do not articulate the details of their dynamic $\mathrm{S} \rightarrow \mathrm{P} \rightarrow \mathrm{C}$ construct $^{5}$ neither of their "competitive position" construct, missing to give a clear overview of how the structure might influence the company position and performance.

The model of interdependence between companies' competitive position resulting from industrial structure influence and the company's strategic behaviour has to be further articulated, which has been done by this study.

Competitive position of the company should indicate the industrial position the company has already taken in relation to direct industry competitors. In this sense, the competitive position of the company is a comparative resultant of the shape (direction) and the intensity of the factors of industrial structure on the company. Individually observed influence of the factors of industrial structure on the company will be the absolute value of company's performance, if they are considered as the result of company's performance in interaction with its industrial environment. By introducing the competitive position in the context of the S-C-P paradigm, its last two elements are inverted: conduct $(\mathrm{C})$ and performance $(\mathrm{P})^{6}$. This provides a stronger relationship between the two

\footnotetext{
${ }^{4}$ For Porter these are differentiation, focusing and cost leadership, and for Miles and Snow prospector, analyzer, defender and reactor types of company's strategic behavior.

${ }^{5}$ The authors mention the "dynamism" of interdependence (of perceived effects) of factors of industrial structure, and they explain the existence of three different observation periods for observing the influence of industrial structure on company's strategic behaviour in the time periods of the same length. The three different periods of observation of the given constructs are empirically joined into one variable of the "overall" influence/effect of structure, i.e. "the most common" pattern of strategic behaviour.

${ }^{6}$ It is important to emphasize that the performances of companies in the classical S-C-P process represent the financial aspects of company's performance, while in the proposed S-P-C process performances are treated as a resultant of company's performance in interaction with the industrial environment.
} 
Figure 2. Conceptualization of the company competitive position within the S-C-P paradigm

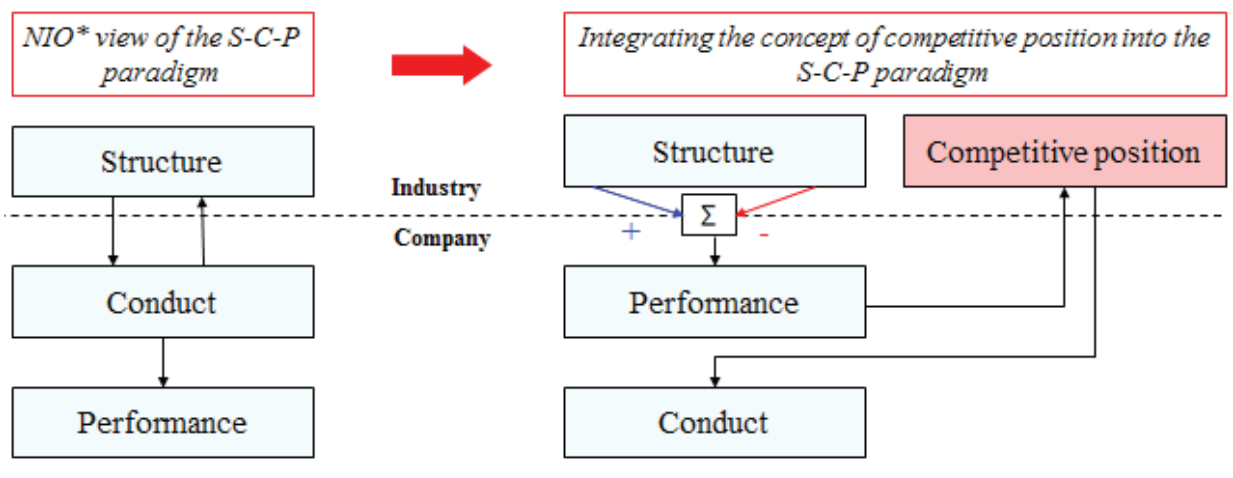

*New Industrial Organization

levels of conceptualization of the theoretical model proposed by this paper: the industrial level and the company level (Figure 2).

The proposed view of the traditional S-C-P process emphasizes the relevance of the complementary relationship of the traditionally conflicting positions from which factors affecting the performance of the company are observed: external (from the outside) and internal (from the inside).

Consequently, company management should strive to take the optimal competitive position in the industrial environment (external factors of influence) by implementing the process of strategic positioning (by changing the internal factors of influence).

\section{DYNAMIC MODEL FOR DETERMINING THE OVERALL COMPETITIVE POSITION OF A COMPANY IN THE INDUSTRIAL ENVIRONMENT}

Company's current competitive position in the industrial environment will depend on the previous one and will be determined by the current influence of the factors of industrial structure (Figure 3).
The current impact of competitive forces will enable management to gain an insight of own strengths and weaknesses, in relation to individual factors that determine individual industrial forces. Porter (1979: 138) states that competitive forces "...highlight the critical strengths and weaknesses of the company, animate the positioning of the company in its industry". Pecotich et al. (1999: 421) support the above by claiming that "knowledge of the five forces of competitive pressure also highlights the strengths and weaknesses of a firm, and forms a useful basis for the evaluation of its position in the industry".

Considering that the business environment has been becoming much more dynamic since the 1980 s, one of the key structural weaknesses of the five-force model is its implied static nature (Macmillan \& Tampoe, 2000; Grant, 2002; Sheehan, 2005; Karagiannopoulos et al., 2005; Stonehouse \& Snowdon, 2007; Dulčić et al., 2012). In times of stable and predictable development of most industries, the existing constellation of competitive forces revealed its future character. At the time, taking a favourable competitive position meant a relative longterm stability.

However, the development of alternative strategies, that is finding new forms 
Figure 3. Structural model of the current (existing) company competitive position in the industrial environment

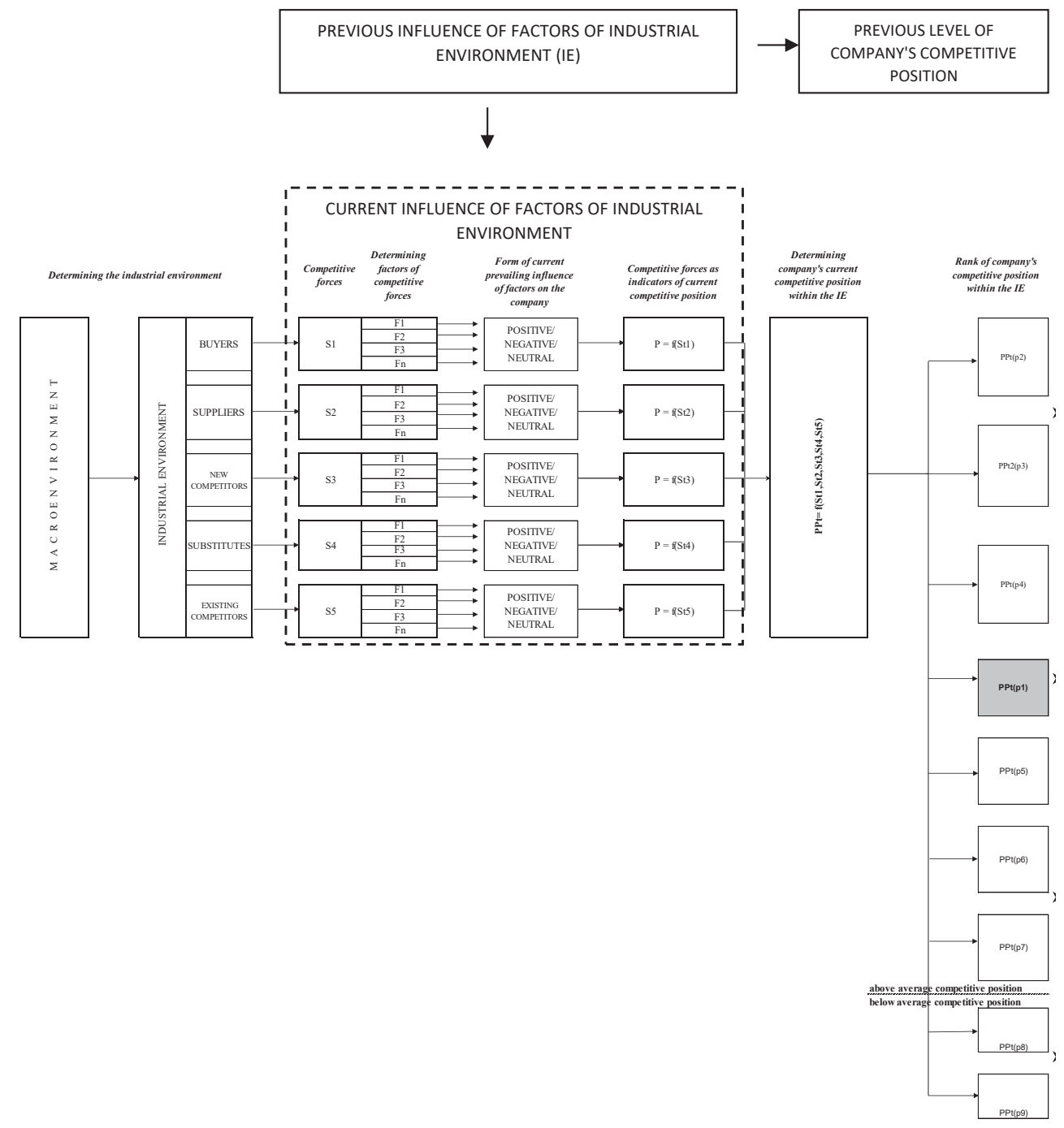

of strategic orientation, based on the established current competitive position of a company, is not an optimal approach in the contemporary competitive environment. Porter (1997, 2008) points out that, after determining the strengths and weaknesses, within the framework of the existing industrial structure, management should detect the areas in which the industry trends prove to be most significant, thus, suggesting the starting point for company's future strategic action.

Therefore, in contrast to the analysis of effects of industrial factors in a single moment (now), the needs of modern industrial development require the model to be enhanced with dynamic features. By observing and quantifying the impact of industrial environment factors on the competitive position of a company, it is possible to study their 
impact on the dynamic (previous, current, and anticipated) and the holistic (overall) competitive position of a company in the industrial environment (Dulčić et al., 2012).

By analogy to the two-way relation between the structure $(\mathrm{S})$ and conduct $(\mathrm{C})$ as elements of the S-C-P process ${ }^{7}$, opportunities and threats from the industrial environment can be interpreted as factors determining the future impact of the industrial structure. This can be done in two ways: (1) as a resulting sum of the company's future response(s) to current opportunities and threats and (2) as the future resulting sum of the direction of company's current strengths and weaknesses - arising from the current impact of industrial factors. In a similar way, Porter et al., (2000), when describing the environmental

Figure 4. Structural model of company's anticipated (expected) competitive position in the industrial environment

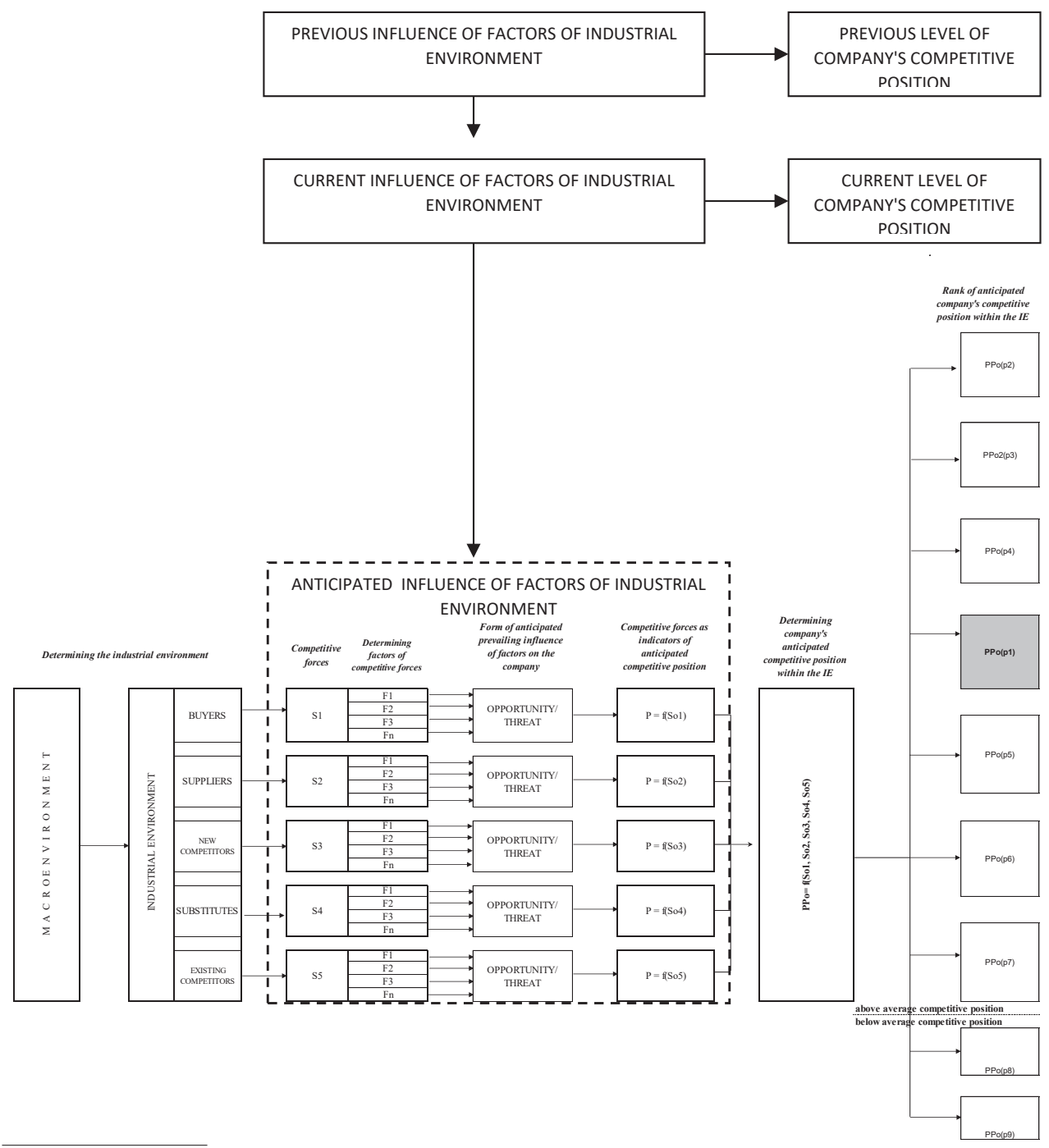

\footnotetext{
${ }^{7}$ In accordance with the advocates of the New Industrial Organization (NIO), i.e. M.E. Porter.
} 
strengths, claim that they change over time and may be either opportunities or threats to the company. Nevertheless, Porter's analytical concept has still not been developed in the dynamic sense, nor has it been formulated so as to serve as an analytical tool.
Therefore, it is necessary to anticipate $f u$ ture competitive position of a company as a determinant of the expected impact of key factors of industrial structure (Figure 4).

Figure 5. Structural model of company's overall (holistic, hybrid) competitive position in the industrial environment

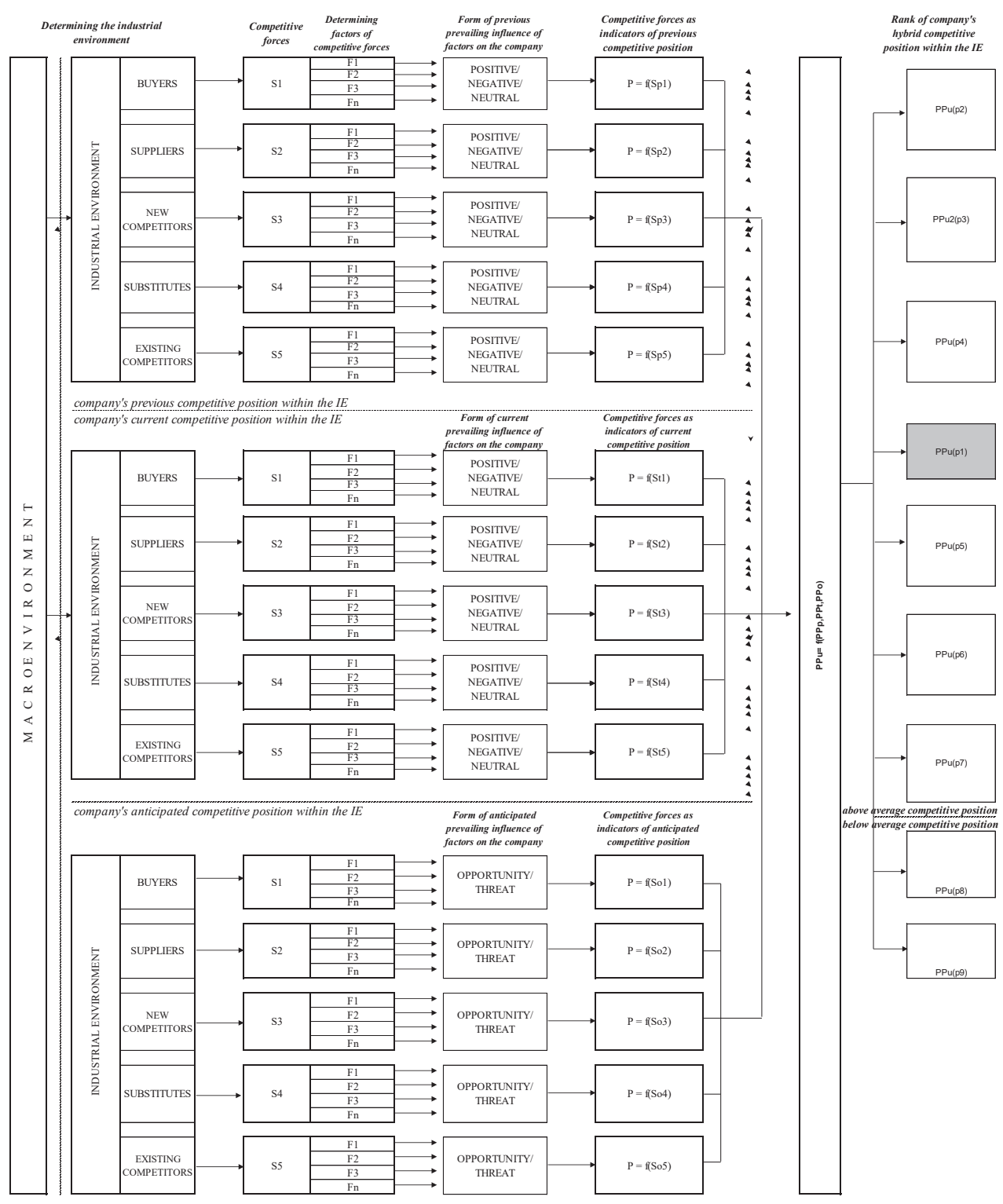


The expected impact of competitive forces can either intensify the existing strengths or lessen the existing company weaknesses (opportunities), or they can have the opposite effect (threats). It is the anticipated competitive position of the company that enables the management to develop alternative strategies to encourage the expected positive impact of the elements of the micro-environment, or discourage the negative ones. Factors of the current competitive environment should correlate, to a large extent, with those that influence the anticipated competitive position, if the strategic orientation does not change significantly. However, along with the evaluation of the expected impact of factors of industrial structure, the management also has to face the task of selecting optimal strategic orientation. The context of future competitive position will also indicate the often emphasized shortcomings of the "five forces" concept.

Figure 6. Conceptualization of belonging to a group of companies with similar overall competitive position in the industrial environment

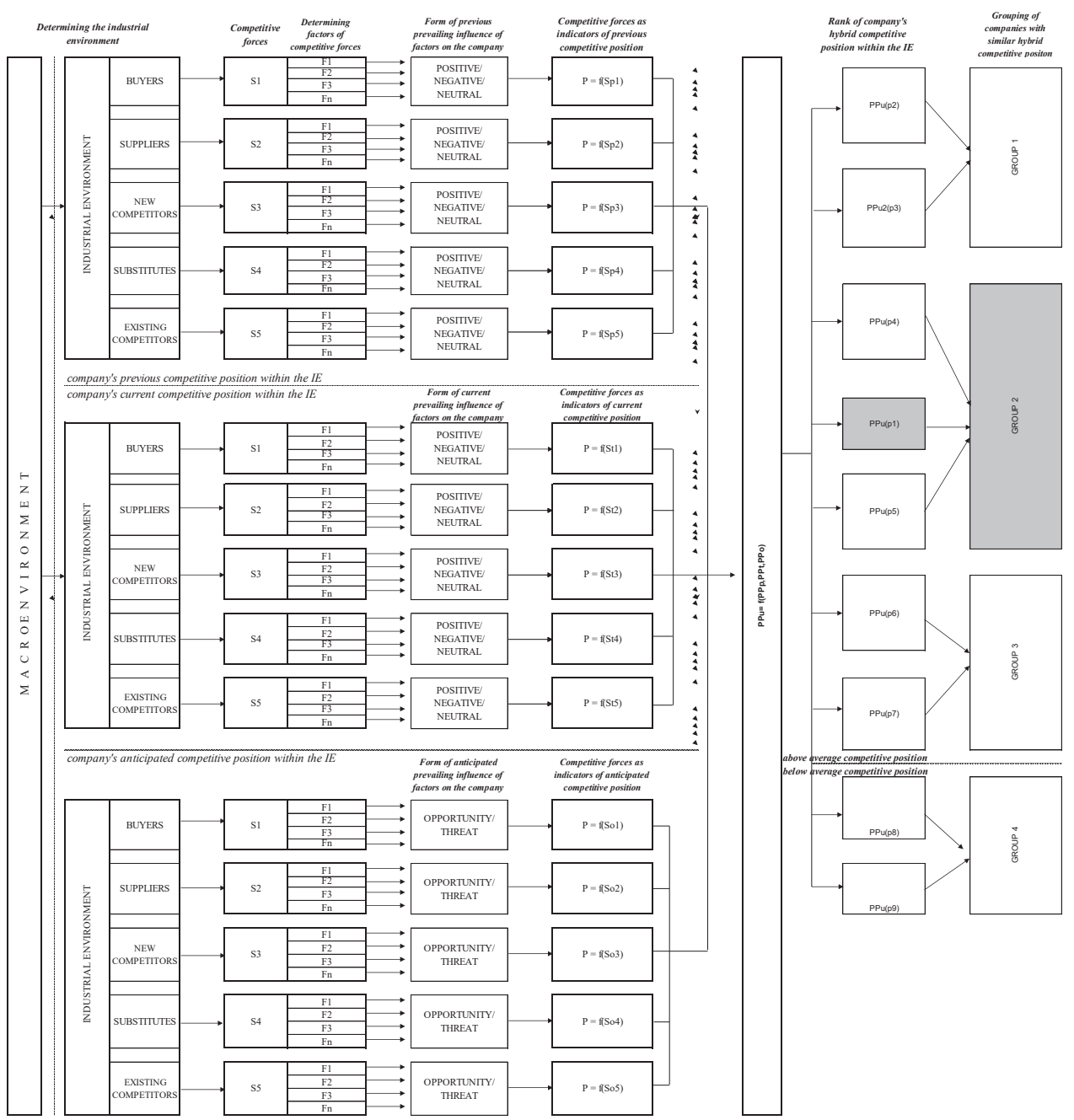


Having analysed the company's current and anticipated competitive position; it is possible to introduce the comprehensive (hybrid) analysis. Such an analysis aims to identify the overall, dynamic competitive position in a dynamic industrial environment (Figure 5). The overall competitive position will indicate the total difference in type and intensity of each particular competitive force, as well as of all the forces together, from the point of view of the observed company. The overall success of the competitive position will be constructed by taking into account three different perspectives: the previous, the current and the anticipated type and intensity of impact of the industrial structure.

The problem of determining a company's competitive position also has to be approached from a broader perspective in order to find out if there are competitors' groups with similar strategic position within the observed industry (Figure 6). Familiarity with the existing strategic groups provides an insight into the current position of the company within the immediate competitive environment, as well as enables the management to define the attractiveness of the given position. Company's strategic goal can be expressed through strengthening the position within the strategic group the company belongs to, or shifting into another, more appropriate group. Familiarity with the corresponding group provides an insight into the existence and the size of barriers of mobility to each strategic group.

Porter's analytical concept of extended rivalry, placed into the dynamic framework, is believed to present the key contribution of the proposed model.

\section{THEORETICAL MODEL OF INTERDEPENDENCE OF COMPANY'S COMPETITIVE POSITION AND ITS STRATEGIC ORIENTATION}

The process of strategic formulation is based on the adjustment of the types of company's strategic behaviours to the environmental conditions, regarding its existing or desired competitive position (Porter, 1979, 1980, 1985, 1998; Miles and Snow, 1978). There is still no theoretical consensus on the importance of the analysis of external opportunities and threats arising from the industrial environment versus resourceoriented analysis of company's internal strengths and weaknesses (Mintzberg, 1987; Hoskisson et al., 1999). Accordingly, there is no theoretical consensus on the nature of their relationship, which leaves open the possibility for further research aimed at understanding the complex relations between a company's environment and its strategic action.

The interdependence of a company and its environment is in the focus of much research and theoretical discussion. Miller (1988) reports a strong relationship of company strategy with the environment. This form of reciprocity is referred to as market rule. While the environment can (and should) affect the selected business strategy, on the other hand a strategy can affect the environment. The author remarks that the mutual causality of environment and strategy has an impact on company performance, where poor adaptation can potentially result in below-average performance. He finds out that the most successful groups of companies have also adapted most successfully. Tipurić (1996) discusses development of an effective business strategy as an objective of industrial analysis in companies. He considers the company's strategic 
action in the industry to be dependent on the existing and future industrial structure. Hussey (1998), as well as DeOliviera and Fensterseifer (2003), claim that events in the environment have a direct impact on the success or failure of the company concerned. Kald et al. (2000) conclude that the management is presented with the challenge of building an internal (organizational) system, "focused on the consistent implementation of the selected strategic orientation, with sufficient flexibility that will enable it to adapt to the changing conditions in the environment". Referring to the conclusion put forward by Hooley et al. (1998), that the recent strategies of competitive positioning "put equal emphasis on market needs, as well as on company's possibilities in selecting the target markets/segments and implementation of positioning strategies", Morgan et al. (2003) point out that "recent studies research the position of the company in its product market, with a focus on establishing relationships between internal resources and the company behavior, as well as its perceived position in its external environment."

Besides numerous studies that confirm or deny ${ }^{8}$ the impact of environment on the company, Morgan et al. (2003) emphasize that "there is still no adequate level of knowledge to explain the relationship between product-market position and the ways of implementing the competitive strategy". This encourages further efforts in studying forms and relevance of the relationship between the relative position of the company in its competitive environment and its strategic orientation.

Therefore, it makes sense to link the strategic orientation construct to the company's competitive position. By creating a model that links the company's overall competitive position, on the one hand, and its overall strategic orientation as a dominant pattern of behaviour, on the other, it is possible to further contribute to understanding the relationships between the environment and the company.

Strategic choice is the foothold of the Miles and Snow's concept of strategic orientation (1978), as one of the most complex theoretical frameworks. Managers' choices of the patterns related to strategic behaviour represent an internal focus, created by relationships of the company's product-market domain, technology and organizational structure. On the other hand, Porter (1980, 1985) focuses on ways of building the competitive advantage resulting from the company's position in the competitive environment. Internal focus of Miles and Snow's strategic typology and Porter's external focus of company's relative position, within the framework of extended rivalry, when combined, provide an insight into the adequacy of company's strategic properties and the existence of adaptation to the industrial environment (Figure 7).

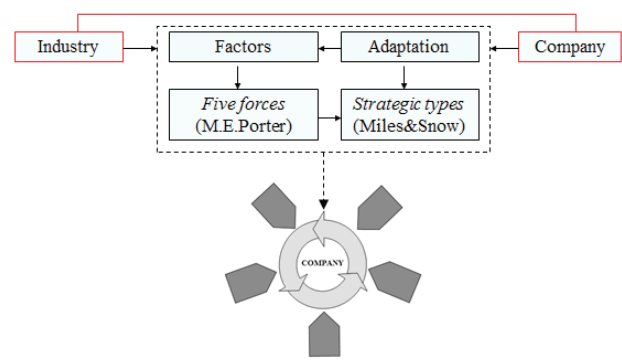

Figure 7. The company as the focus of the combined observation using Miles \& Snow's and Porter's models

The circular connection shown by dashed lines in Figure 7 indicates a logical

\footnotetext{
${ }^{8}$ E.g. Hawawini et al.'s (2003) research indicates a lack of links between the industrial effects and company's performances.
} 
justification for merging the models. Miles and Snow's strategic types are defined by the type of adaptation to the factors of the environment. Factors of the environment are defined by Porter's competitive forces. The circular character of the described relations implies influence of the competitive forces on the selection of one of the different types of company's strategic orientation. A successful adjustment of each particular strategic type to competitive forces will depend on the "level of adaptation" of the elements of the adaptive cycle.

It is precisely because of its focus on different characteristics of business strategy that the separate evaluation of Miles and Snow's strategic pattern and Porter's strategic position, conducted on a sample of equal companies, should provide a deeper insight into the relevance and interaction of competitive position and strategic behaviour. By applying the combined model, the strategic adaptation, as a Miles and Snow's typology construct, would obtain a realistic frame, not based solely on the relationship between the strategic behaviour and the company's (financial) performance as a measure of its success. It would stand on the relative position of the company in a competitive environment that exercises specific effects on all industrial participants. The success of the company thus acquires a broader context, transcending the traditional financial and non-financial performance indicators. The level of competitive position will indicate company success as a relative category, with the hypothetical existence of relationship with performances. Transcending the usual presentation of success through the financial/non-financial performances should be best manifested in a comparative analysis of companies with equal pattern of strategic behaviour and similar financial / non-financial performances. Overall competitive positions of the observed companies should define their comparative success. In accordance with the above is Kald et al.'s (2000) conclusion that it is "to be expected that there will be companies of equal strategic pattern but of different strategic positions". By observing both the strategic pattern and the competitive position, it will be possible to recognize the existence or reciprocity of their change, following the implementation of strategic change. Changing the pattern of strategic orientation, or one of its components, does not need to result in a change of company's competitive position. The desired competitive position of the company may, but need not, mean the change of pattern of strategic orientation or one of its parts. Understanding this reciprocity is the focus of the theoretical model of interdependence of company's competitive position and its strategic orientation in the industrial environment (Figure 8).

In modelling the relationship of the two variables, the relation between the company's current competitive position and the current form of strategic orientation should first be considered (Figure 9). The established mutual harmony or deviation will reflect the adequacy of the current strategic response to the environment.

Besides determining the previous or current it is also necessary to anticipate the planned form of company's strategic behaviour ${ }^{9}$, and define the possibilities of changing the strategic type to which the company belongs. This will also enhance the basic Miles and Snow's model, frequently criticized for its static nature (Gnjidić, 2014).

\footnotetext{
${ }^{9}$ Shortell and Zajac (1990) suggest further research, in particular that of the future behaviour of strategic types. In line with this view of the analysis of company's strategic orientation is the Mintzberg's (1989: 27) definition of strategy as "a combination of the future plans and the past patterns of behaviour".
} 
Management, Vol. 23, 2018, No.2, pp. 103-121

V. Gnjidić: INTERDEPENDENCE OF COMPANY'S INDUSTRIAL...

Figure 8. Relationship of the industrial structure and different types of strategic orientation

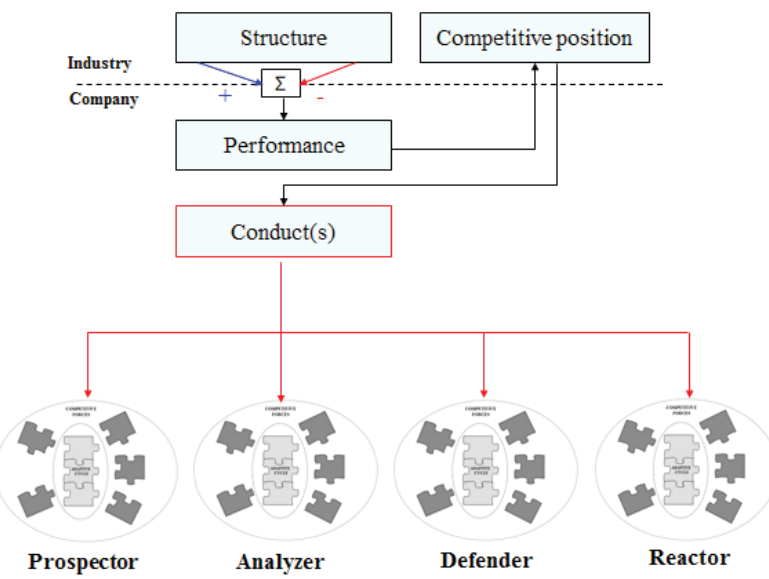

Figure 9. Theoretical conceptualization of existing (current) reciprocity of the competitive position and the strategic orientation of the company

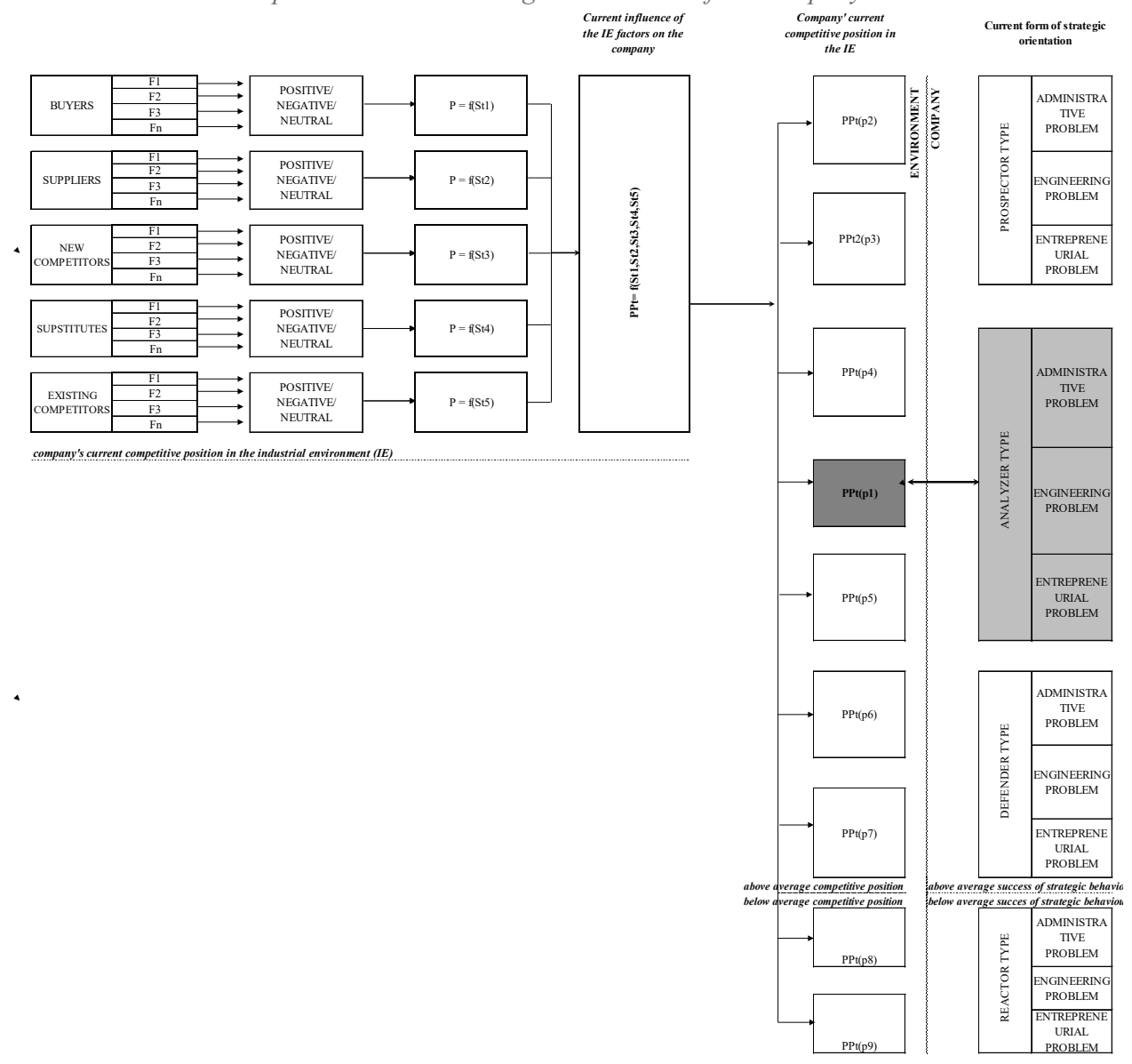


Figure 10. Theoretical conceptualization of the dynamic reciprocity of company's competitive position and strategic orientation

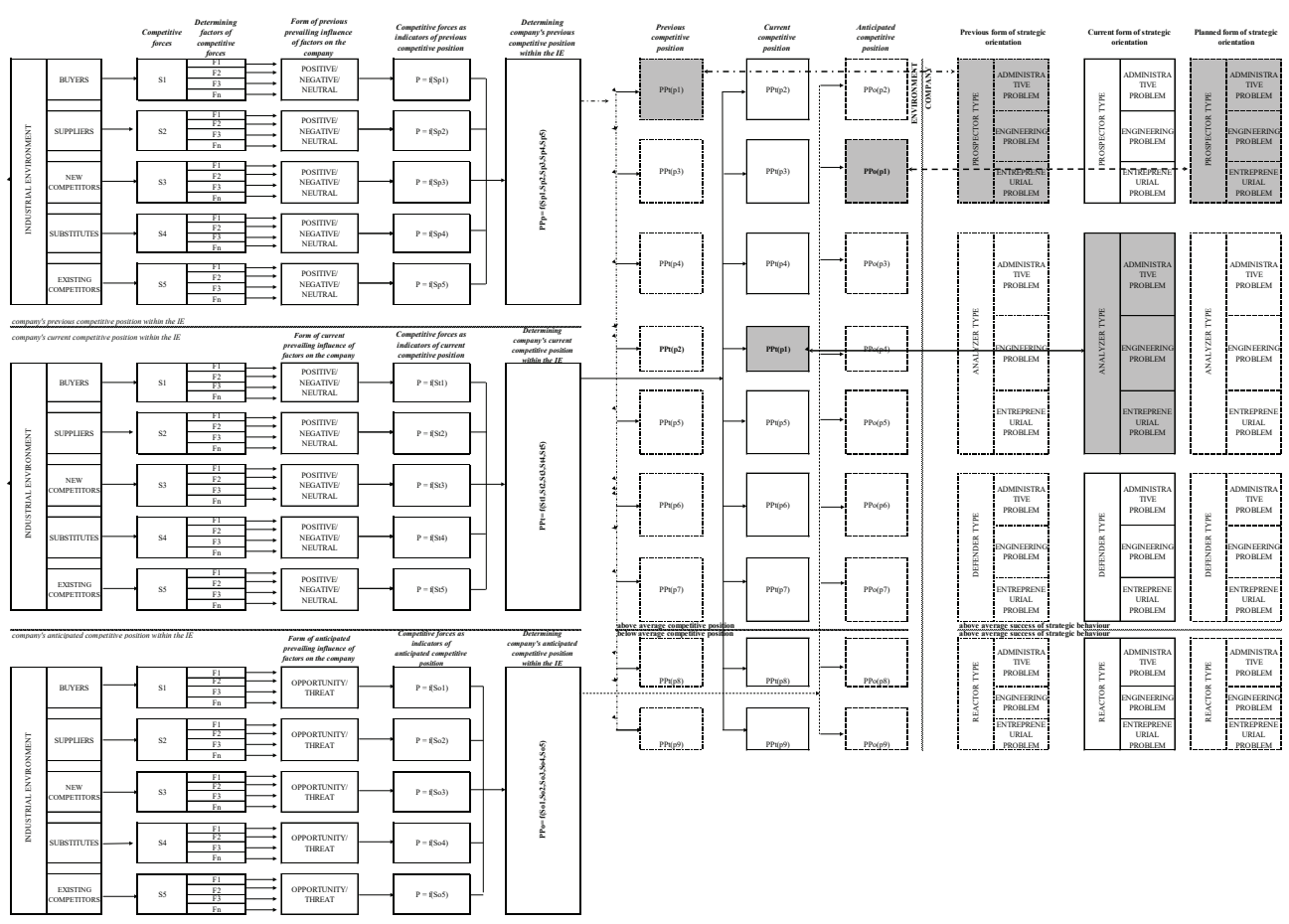

It is necessary to determine whether there is a correlation between the previous, current and anticipated company's competitive position within the observed industrial environment and its previous, current and planned pattern of strategic behaviour (Figure 10), and what kind of correlation this is. The correlation between the aboveaverage industrial position of the company and the above-average successful strategic behaviour should indicate a consistent adaptation of the company to the environment. On the other hand, a lack of correlation should indicate the need to review the adequacy of the company's industrial position or to change its strategic direction, in order to achieve a higher level of adaptation to the business environment.

From the point of view of the overall competitive position in the industrial environment, it is necessary to consider its relationship with the dominant form of strategic orientation, the one prevailing in all three observed periods. Theoretically, a consistent pattern of strategic behaviour, that is one of the successful strategic types (prospector, analyst, defender), should also take the above average overall (hybrid, holistic) competitive position. Accordingly, groups of companies of similar overall competitive position theoretically apply the identical form of strategic adaptation to the environment (Figure 11).

\section{CONCLUSION}

Research goal of the paper was met by proposing a theoretical model framing the correlation between company's competitive 
Figure 11. Reciprocity of the company's overall (hybrid, holistic) competitive position and the dominant strategic orientation

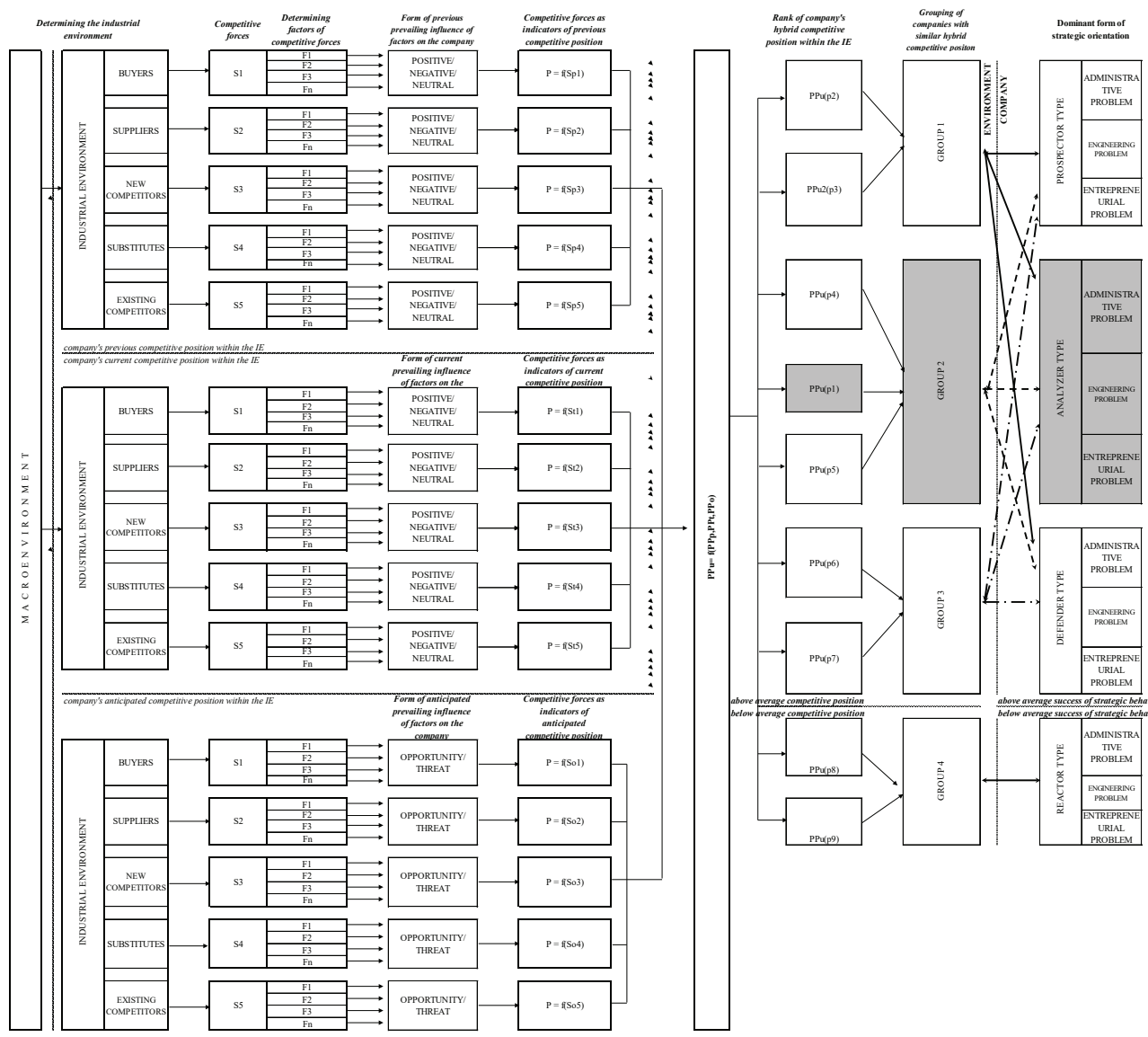

position in an industry with its strategic behaviour pattern over a longer period of time.

Answers to three research questions were provided.

1) Company's competitive position in industrial environment was defined using reverted elements of the S-C-P paradigm. Determinants of industry structure (S) were defined using "five competitive forces" (Porter, 1979). Their positive and negative influence on company's performance (P) were summed and brought back on industry level enabling a relative comparison to other companies' competitive positions.
2) Company's dynamic competitive position was framed measuring positive and negative impacts of five competitive forces over three consecutive periods: past, current, and anticipated.

3) Dynamic interdependence between company's competitive position and its strategic behaviour was conceptualized linking past, current and anticipated influence of five competitive forces with past, current and planned types of strategic behaviour defined as Mile and Snow's (1978) strategic types. 
Theoretical application of the paper is in its contribution to the dynamism of both Porter's (1979) and Miles and Snow's (1978) original models. Interdependency model between competitive forces and strategic behaviour typology proposes potential approach in linking structure (S) to conduct (C) as integral elements of the S-C-P paradigm. The level of company's competitive position in an industrial environment, in dependence with the implemented pattern of strategic orientation, should determine "suitability" of the strategic orientation to the environmental conditions. Low competitive position of a company of a particular type of strategic behaviour (prospector, analyser, defender or reactor) will indicate inadequacy of the selected strategic pattern or its inconsistent implementation. Different competitive position of companies that apply the same strategic pattern in the same industrial environment will indicate the difference in the elements of the adaptive cycle. Parallel awareness of company's competitive position and the strategic orientation pattern could undoubtedly serve as an evaluation tool for determining the adequacy of the previous and current strategic behaviour, selecting an optimal future

\section{References}

1. Alfirević, N., Pavičić, J., \& Gnjidić, V. (2014). Cognitive Structure, Manager's Shared Social Understanding: From Psychological and Sociological Concepts to Managerial Strategic Choices. International Review of Economics and Business, XVII (2), 83-96.

2. Bain, J.S. (1951). Relation of Profit Rate to Industry Concentration: American Manufacturing 1936-1940. Quarterly Journal of Economics, August, 293-324. competitive position, or choosing the optimal strategic pattern.

Practical application is with the proposed way to operationalize five competitive forces offering a proposal for potential future empirical validations. The implementation of the proposed theoretical interdependence model of company's industrial competitive position and its strategic orientation could serve as a strategic planning tool for both: intra-industry and inter-industry strategic analysis. As strategic planning process in companies often relies on past performance, combining past with current and future pattern of strategic behaviour in correlation with competitive position might lead to clear(er) strategic choices.

The proposed conceptual model of the dynamic interdependence between the organizational competitive position and the strategic orientation should be validated in a selected industry over various periods of time (Alfirević et al., 2014). In addition, in order to validate the model's potential of generalization, an empirical validation of the model might be carried out in a variety of industries in parallel time periods.

3. Bourgeois, L.J. (1984). Strategic management and determinism. Academy of Management Review, 5, 25-39.

4. Chen, M.-J. (1996). Competitor analysis and interfirm rivalry: Toward a theoretical integration. Academy of Management Review, 21, 100-134.

5. De Oliviera Wilk, E., \& Fensterseifer, J.E. (2003). Use of resource-based view in industrial cluster strategic analysis. International Journal of Operations\& Production Management, 23 (9), 995-1009. 
6. Desarbo, W.S., Di Benedetto, C.A., Song, M., \& Sinha, I. (2004). Revisiting the Miles and Snow Strategic Framework: Uncovering Interrelationships between Strategic Types, Capabilities, Environmental Uncertainty, and Firm Performance. Strategic Management Journal, Online publication www.interscience.wiley. com, 29/05/2008.

7. Dess, G.G., Ireland, R.D., \& Hitt, M.A. (1990). Industry Effects and Strategic Management Research. Journal of Management,16 (1), 7-27.

8. Dulčić, Ž., Gnjidić, V., \& Alfirević, N. (2012). From Five Competitive Forces to Five Collaborative Forces: Revised View on Industry Structure-Firm Interrelationship, 8th International Strategic Management Conference, Elsevier Ltd. Selection, Procedia Social and Behavioral Sciences, 58.

9. Eng, T-Y. (2004). Does customer portfolio analysis relate to customer performance? An empirical analysis of alternative strategic perspective. Journal of Business \& Industrial Marketing, 19 (1), 49-67

10. Fahy, J., \& Smithee, A. (1999). Strategic marketing and the resourcebased view of the firm. Academy of Marketing Science Review, 10,www. amsreview.org/amsrev/theory/fahy 1099.html, 01.06.2008.

11. Gnjidić, V. (2014). Researching Dynamics of Miles's and Snow's Strategic Typology. Management Journal of Contemporary Management Issues, 19 (1), 93-118.

12. Grant, R. M. (2002). Contemporary Strategy Analysis: Concepts, Techniques, Applications, Blackwell Publishers.

13. Hambrick, D.C. (1983). Some Tests of the Effectiveness and
Functional Attributes of Miles and Snow's Strategic Types. Academy of Management Journal, 26 (1), 5-26.

14. Hawawini, G., Subramanian, V., \& Verdin, P. (2003) Is performance driven by industry-or firm-specific factors? A new look at the evidence. Strategic Management Journal, 24,1-16.

15. Hooley, G., Broderick, A., \& Moller, K. (1998). Competitive positioning and the resource-based view of the firm. Journal of Strategic Marketing, 6, 97-115.

16. Hoskisson, R.E., Hitt, M.A., Wan, P.W., \& Yiu, D. (1999). Theory and research in strategic management: Swings of a pendulum. Journal of Management, 25(3),417-456.

17. Hussey, D. (1998). Strategic management: from theory to implementation, 4ed. Oxford: Butterworth-Heinmann.

18. Jemison, D.B. (1981). The importance of an integrative approach to strategic management. Academy of Management Review, 6, 601-608.

19. Jones, G., George, J.M., \& Hill, C.W.L. (2000). Contemporary Management, McGraw-Hill.

20. Kald, M. Fredrik Nilsson, F., \& Rappt, B. (2000). On Strategy and Management Control: The Importance of Classifying the Strategy of the Business. British Journal of Management, 11, 197-212.

21. Karagiannopoulos, G.D., Georgopoulos, N., \& Nikolopoulos, K. (2005). Fathoming Porter's five forces model in the internet era, Emerald Group Publishing Limited,7(6), 66-76.

22. Kippenberger, T. (1998). Strategy according to Michael Porter, The Antidote, 3 (16), 24-25.

23. Macmillan, H., \& Tampoe, M. (2000). Strategic Management. Oxford: Oxford University Press. 
24. Miller, D. (1988). Relating Porter's business strategies to environment and structure: analysis and performance implications. Academy of Management Journal, 31, 280-308.

25. Miles, R.E., \& Snow, C.C. (1978). Organizational Strategy, Structure, and Process. Stanford University Press.

26. Mintzberg, H. (1989). Inside Our Strange World of Organizations. The Free Press.

27. Mintzberg, H. (1987). The Strategy Concept I: Five Ps For Strategy. California Management,

28. Morgan, R.E., Strong, C.A., \& McGuinness, T. (2003). Productmarket positioning and prospector strategy: An analysis of strategic patterns from the resource-based perspective. European Journal of Marketing, 37 (10), 1409-1439.

29. Pecotich, A., Hattie, J., \& Low, L.P. (1999). Development of Industruct:

A Scale for the Measurement of Perceptions of Industry Structure. Marketing Letters, 10 (4),409-422.

30. Porter, M.E. (1979). How Competitive Forces Shape Strategy. Harvard Business Review, March-April, 137-145.

31. Porter, M.E. (1981). The Contributions of Industrial Organization To Strategic Management. Academy of Management Review, 6 (4),609-620.

32. Porter, M.E. (2008). The Five Competitive Forces that shape Strategy.
Harvard Business Review, January, 78-93.

33. Porter, M.E. (1991). Toward a Dynamic Theory of Strategy. Strategic Management Journal, 12, Winter, 95-117.

34. Rumelt, R.P. (1991). How much does industry matter?. Strategic Management Journal, 12, 167-185.

35. Sheehan, N.T. (2005). Why old tools won't work in the "new" knowledge economy, Journal of Business Strategy, 26 (4), 53-60.

36. Shortell, S. M., \& Zajac, E.J. (1990). Perceptual and Archival Measures of Miles and Snow's Strategic Types: A Comprehensive Assessment of Reliability and Validity. Academy of Management Journal, 817-832.

37. Stonehouse, G., \& Snowdon, B. (2007). Competitive Advantage Revisited: Michael Porter on Strategy and Competitiveness. Journal of Management Inquiry, 16 (3), 256-273.

38. Tipurić, D. (1996). Porterov model industrijske strukture (Industrijska analiza kao ključna pretpostavka oblikovanja strategije poduzeća). Poslovna analiza i upravljanje, 28-37.

39. Yong-Kim, B. \& Oh, H. (2004). How do hotel firms obtain a competitive advantage? International Journal of Contemporary Hospitality Management, 16 (1), ,65-71. 